\title{
BIOKONTROL ENDOMIKORIZA TERHADAP JAMUR Curvularia SP. PENYEBAB PENYAKIT TANAMAN JAGUNG (Zea mays L.)
}

\section{BIOKONTROL ENDOMYCORRHIZA AGAINST FUNGUS Curvularia sp. THE CAUSE OF DISEASE ON CORN (Zea mays L.)}

\author{
Lily Windasari, Meitini Wahyuni Proborini, Made Ria Defiani \\ Program Studi Biologi, FMIPA, Universitas Udayana \\ Email: pmeitini@yahoo.com
}

\begin{abstract}
ABSTRAK
Di Indonesia, produksi jagung dimanfaatkan sebagai makanan ternak 55\%, makanan pokok $30 \%$ dan keperluan benih $15 \%$. Penurunan produksi jagung dapat diakibatkan oleh patogen Curvularia sp. yang menyebabkan bercak pada daun jagung. Penggunaan endomikoriza dapat dimanfaatkan sebagai agen hayati dalam mencegah terjangkitnya patogen. Penelitian ini menggunakan metode yang digunakan yaitu penyemprotan isolat jamur Curvularia sp. pada bibit tanaman jagung. Penelitian dilaksanakan di laboratorium dan green house. Bibit jagung ditumbuhkan pada media tanah steril (kontrol), perlakuan mikoriza (mikoriza $100 \mathrm{~g}+$ Curvularia sp., mikoriza $200 \mathrm{~g}+$ Curvularia sp., mikoriza $300 \mathrm{~g}+$ Curvularia sp.) dan Curvularia sp. selama 60 HST variabel yang diamati yaitu jumlah daun, laju perkembangan penyakit dan berat basah serta berat kering tanaman. Hasil penelitian menunjukkan dengan inokulum 100 g CMA dapat meningkatkan pertumbuhan jagung fase pembibitan. Peningkatan dapat dilihat dari berat basah akar mencapai 27,04\% dan berat kering akar sebesar 26,57\%. Peningkatan persentase kolonisasi mikoriza hingga 58,66\% sehingga dapat digunakan untuk menurunkan infeksi patogen pada tanaman jagung umur 28 hari setelah tanam.
\end{abstract}

\section{Kata kunci : bibit, bercak daun, agen hayati}

\begin{abstract}
In Indonesia, production of corn are used for fodder (55\%), food (30\%), and seed $(15 \%)$. The growth of corn plants is limited by the presence of pests, weeds, and plant diseases. Curvularia sp. causing leaf spot and could decrease corn production. Use of mycorrhiza can be used as a biological agent in preventing pathogens outbreaks. Isolates of Curvularia sp. fungal was sprayed on corn seed. This research was conducted in laboratorium and green house. Corn seedlings were grown on sterile soil media (control), mycorrhizal treatments $(100 \mathrm{~g}$ of mycorrhizal + Curvularia sp., 200g of mycorrhizal + Curvularia sp., 300g of mycorrhizal + Curvularia sp.) and Curvularia sp. The observed variables were plant height, number of leaves, rate of disease progression, fresh weight and dry weight of plant canopy. The results showed that application of $100 \mathrm{~g}$ inoculum tend to increase plant growth to $26-27 \%$ and percentage of mycorrhizal colonization to $58,66 \%$ thereof can decrease pathogen infection on plant at 28 day after planting.
\end{abstract}

Keywords: seedling, leaf spot, biological agent

\section{PENDAHULUAN}

Jagung (Zea mays L.) merupakan komuditas penting yang setiap tahun mengalami peningkatan produksi mencapai
10-11\% (Akhsan, 2012). Kebutuhan akan jagung dapat mencapai $50 \%$ dari total kebutuhan masyarakat. Komoditi jagung 
baik dari segi teknologi, varietas, produk, sistem dan model dapat berupa kontrak output nyata (Badan Penelitian Pengembangan Pertanian, 2016). Produksi jagung seringkali menurun diakibatkan oleh patogen, infeksi patogen dapat mempengaruhi produksi dan mutu tanaman (Pechanova dan Pechan, 2015). Salah satu hama yang sering menyerang tanaman jagung yaitu ulat penggerek batang, kutu daun, ulat daun, ulat penggerek tongkol, lalat bibit, dan ulat tanah (Susmawati dan Muda, 2014). Penyakit bercak daun, karat, dan bulai sering menyerang tanaman jagung di Indonesia (Haris dan Tenrirawe, 2014). Jamur Curvularia sp. merupakan penyakit yang banyak menyerang tanaman jagung menyebabkan gejala bercak daun. Culvularia sp dapat terjadi pada daerah MATERI DAN METODE

Penelitian ini dilaksanakan pada bulan Desember 2017- Mei 2018 di Laboratorium Mikologi dan greenhouse Program Studi Biologi, FMIPA, Universitas Udayana, Provinsi Bali. Pengambilan sampel dilakukan di Jalan Sedap Malam, Sanur, Denpasar-Bali. Alat dan bahan yang digunakan antara lain: timbangan digital, timbangan analitik ayakan bertingkat, cawan Petri. Bahan yang digunakan dalam penelitian ini meliputi benih jagung, tanah steril, media PDA, isolat jamur Curvularia sp. Penelitian ini menggunakan Rancangan Acak Kelompok (RAK), yang terdiri dari 5 perlakuan dengan 3 kali ulangan setiap kelompok.

\section{Pelaksanaan penelitian}

Penanaman benih jagung dan inokulum CMA

Inokulum yang digunakan dalam penelitian ini adalah Cendawan Mikoriza Arbuskula (CMA) yang diisolasi dari hasil perbanyakan di greenhouse Program Studi bersuhu panas dan lembab (Pechanova dan Muda, 2015).

Pemanfaatan endomikoriza sudah banyak dilakukan dalam bidang pertanian. Endomikoriza merupakan cendawan yang dapat bersimbiosis dengan akar tanaman namun tidak menimbulkan kerugian pada tanaman inang (Suriani dan Muis, 2016). Spora menginfeksi tanaman pada fase perkecambahan. Hifa akan membungkus akar yang berfungsi melindungi dari serangan patogen. Perlu diadakan penelitian untuk mengetahui pengaruh biokontrol mikoriza dalam mencegah penyebab penyakit Curvularia sp. pada tanaman jagung, yang akhirnya menjadi tujuan dari penelitian ini.

Biologi F.MIPA Universitas Udayana. Penyaringan dilakukan dengan ayakan bertingkat, hasil spora yang terkumpul disimpan untuk persiapan pembibitan tanaman jagung di greenhouse. Tanah yang digunakan adalah campuran pasir, tanah liat, dan tanah subur (2:1:2) dimasukan ke polybag sebanyak $5 \mathrm{~kg}$, dan disterilisasi.

Benih jagung ditanam pada polybag berukuran $30 \mathrm{~cm}$ x $25 \mathrm{~cm}$ yang telah berisi media. Tiga benih dimasukan ke dalam tiap polybag. Pada umur 10 HST dipilih satu bibit yang terbaik. CMA inokulasikan pada benih jagung sesuai dosis perlakuan (Tabel $1)$.

\section{Infeksi Patogen Curvularia sp.}

Penginfeksian patogen dilakukan dengan sistem penyemprotan sebanyak $5 \mathrm{ml}$ pada tajuk bibit tanaman yang berumur 10 HST sesuai dosis perlakuan (Tabel 1). Selanjutnya tanaman disungkup selama 24 jam. Hasil pengukuran skor penyakit digunakan untuk menghitung intensitas 
penyakit bercak daun pada masing-masing perlakuan, dengan rumus sebagai berikut:

IS $=\frac{\sum(n \times v)}{N \times Z} \times 100 \%$
IS, intensitas serangan bercak daun; $\mathrm{n}$, jumlah daun; v, skor daun yang diamati; N, jumlah total daun yang diamati; $\mathrm{V}$, nilai skor tertinggi.

Tabel 1. Perlakuan dan dosis perlakuan

\begin{tabular}{ll}
\hline Perlakuan & Dosis Inokulasi CMA dan Patogen Curvularia sp. \\
\hline A & Tanpa perlakuan CMA dan patogen \\
B & Patogen Curvularia sp. \\
C & 100g inokulum CMA + Patogen Curvularia \\
D & 200g inokulum CMA + Patogen Curvularia $\mathrm{sp}$. \\
E & 300g inokulum CMA + Patogen Curvularia $\mathrm{sp.}$
\end{tabular}

\section{HASIL}

\section{Pengaruh Inokulasi Cendawan Mikoriza Arbuskular Terhadap Pertumbuhan Tanaman Jagung (Zea mays L.}

Berdasarkan penelitian yang dilakukan dengan inokulasi 100 g, 200 g, dan $300 \mathrm{~g}$ inokulum CMA. Pertumbuhan jumlah daun menunjukkan perbedaan nyata pada umur 60 HST (Gambar 1). Infeksi mikoriza pada akar tanaman jagung (Zea mays L.) tampak pada perlakuan 100 g, 200 $\mathrm{g}$ dan $300 \mathrm{~g}$ inokulum CMA (Gambar 2).

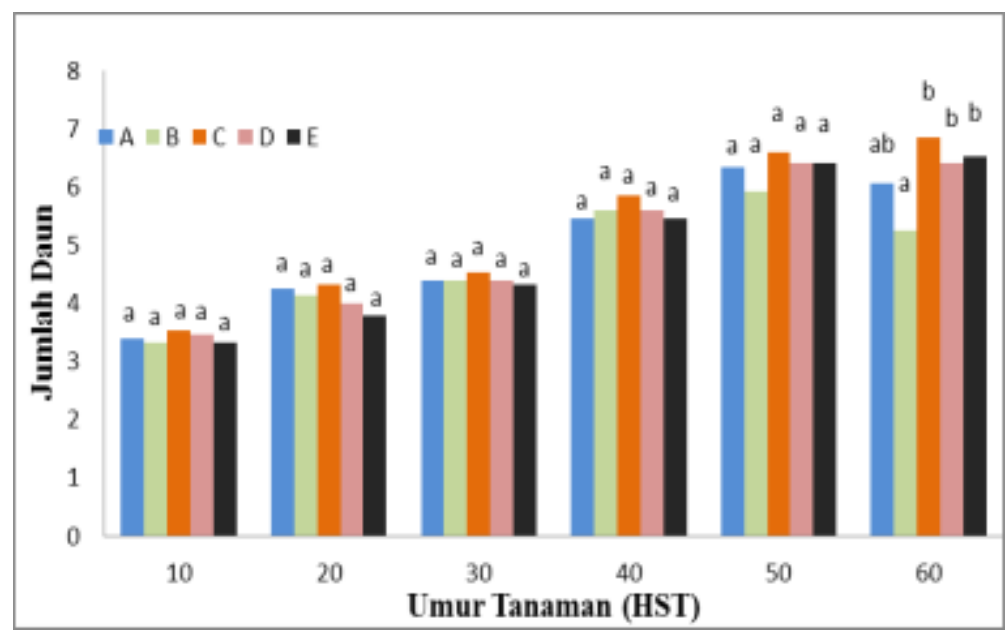

Gambar 1. Rata-rata Jumlah Daun 10-60 HST. A) Tanpa Inokulasi CMA/ Kontrol Negatif, B) Tanpa Inokulasi CMA/ Kontrol Positif + Curvularia sp., C) Inokulasi 100g CMA + Curvularia sp., D) Inokulasi 200g CMA + Curvularia sp., E) Inokulasi 300g CMA + Curvularia sp. 


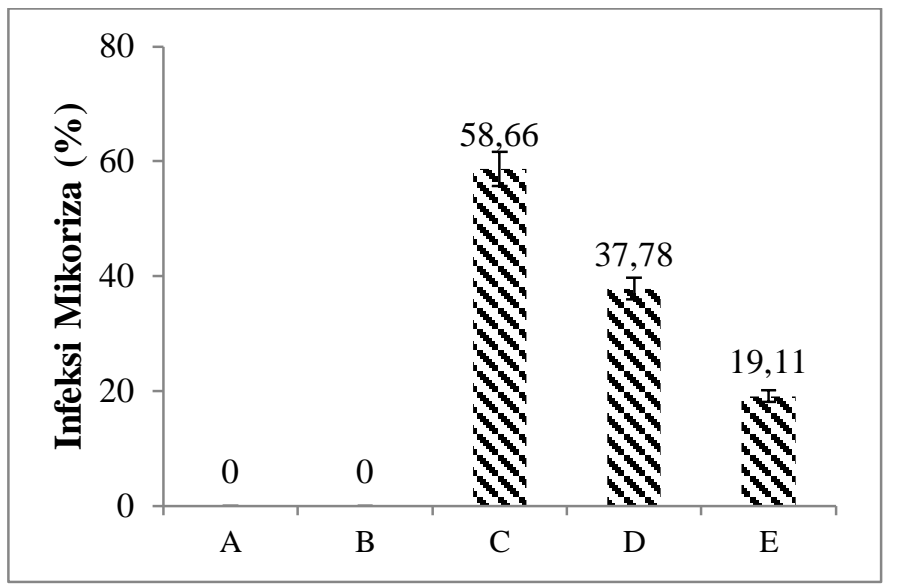

Gambar 2. Infeksi mikoriza pada akar tanaman jagung. A) Tanpa Inokulasi CMA/ Kontrol Negatif, B) Tanpa Inokulasi CMA/ Kontrol Positif + Curvularia sp., C) Inokulasi 100g CMA + Curvularia sp., D) Inokulasi 200g CMA + Curvularia sp., E) Inokulasi 300g CMA + Curvularia sp.

Hasil penelitian pada pengukuran ke-8 parameter yaitu:, lebar daun, panjang daun, berat basah total tanaman, berat basah tajuk, berat basah akar, berat kering total tanaman, berat kering tajuk dan berat kering akar dapat dilihat pada Tabel 2 dan Tabel 3. Berdasarkan analisis statistik ke-9 parameter menunjukkan hasil tidak berbeda nyata.

Hasil pemberian inokulum 100g, 200g, dan 300g CMA pada tanaman jagung yang terinfeksi patogen menurunkan penyakit Curvularia sp. pada umur 28 HST (Gambar 4).

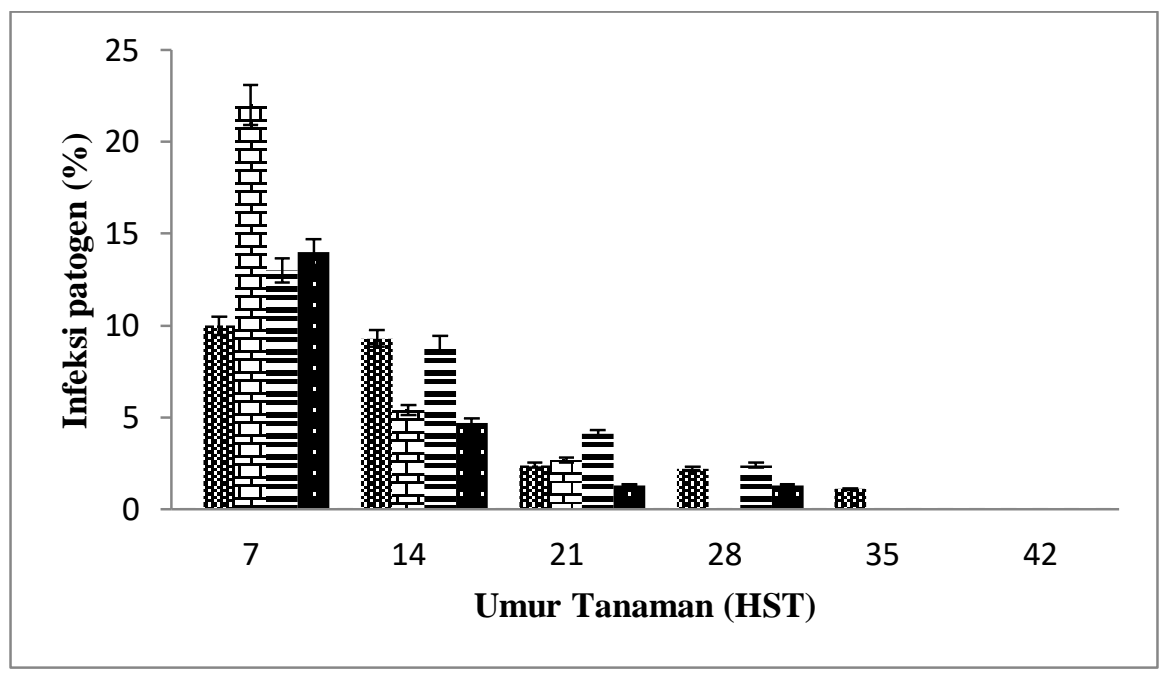

Gambar 4. Tingkat Infeksi Penyakit (\%)

Keterangan:

Kontrol Negatif Mikoriza 200g inokulum + Curvularia $\mathrm{sp}$.
Mikoriza $300 \mathrm{~g}$ inokulum + Curvularia $\mathrm{sp}$.

Mikoriza 100g inokulum + Curvularia sp. 
Tabel 4.1 Rata-rata Panjang Daun, Lebar Daun, Berat Basah Total Tanaman, dan Berat Basah Tajuk Tanaman umur 60 HST

\begin{tabular}{|c|c|c|c|c|c|c|c|c|}
\hline \multirow[b]{2}{*}{ Perlakuan } & \multicolumn{2}{|c|}{ Variabel yang Diamati } & \multirow[b]{2}{*}{ Lebar Daun $(\mathrm{cm})$} & \multirow[b]{2}{*}{$\begin{array}{l}\% \text { kenaikan/ } \\
\text { penurunan }\end{array}$} & \multirow[b]{2}{*}{$\begin{array}{l}\text { Berat Basah } \\
\text { Tanaman }(\mathrm{g})\end{array}$} & \multirow[b]{2}{*}{$\begin{array}{l}\% \text { kenaikan/ } \\
\text { penurunan }\end{array}$} & \multirow[b]{2}{*}{$\begin{array}{l}\text { Berat Basah Tajuk } \\
\text { Tanaman }(\mathrm{g})\end{array}$} & \multirow[b]{2}{*}{$\begin{array}{l}\% \text { kenaikan/ } \\
\text { penurunan }\end{array}$} \\
\hline & Panjang Daun $(\mathrm{cm})$ & $\begin{array}{l}\% \text { kenaikan/ } \\
\text { penurunan }\end{array}$ & & & & & & \\
\hline A & $27,77 \pm 3,82^{\mathrm{a}}$ & 0 & $2,15 \pm 0,57^{a}$ & 0 & $22,76 \pm 7,74^{\mathrm{a}}$ & 0 & $17,99 \pm 5,89^{\mathrm{a}}$ & 0 \\
\hline B & $25,12 \pm 10,70^{\mathrm{a}}$ & 9,54 & $2,18 \pm 1,11^{\mathrm{a}}$ & 1,39 & $18,38 \pm 9,00^{\mathrm{a}}$ & 19,24 & $14,33 \pm 7,74^{\mathrm{a}}$ & 20,34 \\
\hline $\mathrm{C}$ & $27,20 \pm 3,93^{\mathrm{a}}$ & 2,02 & $2,57 \pm 0,52^{\mathrm{a}}$ & 19,53 & $23,90 \pm 6,62^{a}$ & 5,00 & $18,23 \pm 5,06^{\mathrm{a}}$ & 1,33 \\
\hline D & $25,42 \pm 4,74^{\mathrm{a}}$ & 8,46 & $2,12 \pm 0,54^{\mathrm{a}}$ & 1,39 & $22,71 \pm 5,31^{\mathrm{a}}$ & 0,22 & $18,08 \pm 3,61^{\mathrm{a}}$ & 0,50 \\
\hline $\mathrm{E}$ & $25,76 \pm 3,99^{a}$ & 7,23 & $2,14 \pm 0,40^{\mathrm{a}}$ & 0,46 & $20,77 \pm 5,91^{\mathrm{a}}$ & 8,74 & $15,96 \pm 4,50^{\mathrm{a}}$ & 11,28 \\
\hline
\end{tabular}

Tabel 4.2 Rata-rata Berat Basah Akar, Berat Kering Total Tanaman, Berat Kering Tajuk, Berat Kering Akar umur 60 HST

Keterangan

$\mathrm{A}=$ Kontrol Negatif

$\mathrm{B}=$ Kontrol Positif (Curvularia $\mathrm{sp}$.)

$\mathrm{C}=$ Mikoriza $100 \mathrm{~g}$ inokulum + Curvularia $\mathrm{sp}$.

$\mathrm{D}=$ Mikoriza $200 \mathrm{~g}$ inokulum + Curvularia $\mathrm{sp}$

$\mathrm{E}=$ Mikoriza $300 \mathrm{~g}$ inokulum + Curvularia sp.

*Nilai pada table 4 dan 5 merupakan rata-rata dari 5 ulangan \pm standar deviasi. Nilai yang diikuti oleh huruf superscript yang sama pada kolom yang sama merupakan Nilai rata-rata yang tidak berbeda nyata $(\mathrm{P}>0,05)$ berdasarkan uji Tukey pada taraf $5 \%$.

\begin{tabular}{|c|c|c|c|c|c|c|c|c|}
\hline \multirow[b]{2}{*}{ Perlakuan } & & \multicolumn{7}{|c|}{ Variabel yang Diamati } \\
\hline & $\begin{array}{l}\text { Berat Basah Akar } \\
\text { Tanaman }(\mathrm{g})\end{array}$ & $\begin{array}{l}\% \text { kenaikan/ } \\
\text { penurunan }\end{array}$ & $\begin{array}{l}\text { Berat Kering Total } \\
\text { Tanaman }(\mathrm{g})\end{array}$ & $\begin{array}{l}\% \text { kenaikan/ } \\
\text { penurunan }\end{array}$ & $\begin{array}{l}\text { Berat Kering Tajuk } \\
\text { Tanaman }(\mathrm{g})\end{array}$ & $\begin{array}{l}\% \text { kenaikan/ } \\
\text { penurunan }\end{array}$ & $\begin{array}{l}\text { Berat Kering Akar } \\
\text { Tanaman }(\mathrm{g})\end{array}$ & $\begin{array}{l}\% \text { kenaikan/ } \\
\text { penurunan }\end{array}$ \\
\hline $\mathrm{A}$ & $4,77 \pm 2,82^{\mathrm{a}}$ & 0 & $7,78 \pm 2,67^{\mathrm{a}}$ & 0 & $5,25 \pm 1,89^{\mathrm{a}}$ & 0 & $2,22 \pm 1,29^{\mathrm{a}}$ & 0 \\
\hline B & $3,97 \pm 2,09^{\mathrm{a}}$ & 16,77 & $7,17 \pm 3,66^{\mathrm{a}}$ & 7,84 & $4,93 \pm 2,79^{\mathrm{a}}$ & 6,09 & $2,23 \pm 1,32^{\mathrm{a}}$ & 0,45 \\
\hline $\mathrm{C}$ & $6,06 \pm 2,15^{\mathrm{a}}$ & 27,04 & $8,20 \pm 2,08^{\mathrm{a}}$ & 5,39 & $5,38 \pm 1,60^{\mathrm{a}}$ & 2,47 & $2,81 \pm 1,00^{\mathrm{a}}$ & 26,57 \\
\hline $\mathrm{D}$ & $5,33 \pm 2,33^{\mathrm{a}}$ & 11.74 & $7,65 \pm 2,00^{\mathrm{a}}$ & 2.82 & $4,89 \pm 1,65^{\mathrm{a}}$ & 6,85 & $2,76 \pm 1,26^{\mathrm{a}}$ & 24,32 \\
\hline $\mathrm{E}$ & $4,98 \pm 1,82^{\mathrm{a}}$ & 4,40 & $7,56 \pm 2,20^{\mathrm{a}}$ & 2,82 & $4,83 \pm 1,47^{\mathrm{a}}$ & 8 & $2,45 \pm 1,23^{\mathrm{a}}$ & 10,36 \\
\hline
\end{tabular}




\section{PEMBAHASAN}

\section{Pengaruh Inokulasi Cendawan Mikoriza}

\section{Arbuskular Terhadap Pertumbuhan}

Tanaman Jagung (Zea mays L.)

Hasil penelitian in vivo menggunakan inokulasi $100 \mathrm{~g}, 200 \mathrm{~g}$ dan $300 \mathrm{~g}$ inokulum CMA. Dosis inokulasi 100 g meningkatkan jumlah daun sebesar $6 \%$ pada umur 60 HST. Hal ini menunjukkan bahwa infeksi mikoriza baru menghasilkan pengaruh yang nyata terhadap pertumbuhan tanaman jagung. Tanaman jagung 60 HST membutuhkan unsur hara $P$ untuk pertumbuhan dan perkembangan dalam persiapan menuju fase generatif. Unsur $\mathrm{P}$ disediakan oleh mikoriza yang diinokulasi pada bibit jagung.

Rerata jumlah daun dapat dilihat pada Gambar 1. Pengamatan pada 10-50 HST menunjukkan jumlah daun yang sama. Menurut hasil penelitian Masfufah (2015) beberapa pemberian CMA tidak berpengaruh nyata terhadap jumlah daun khususnya pada tanaman yang masih muda. Hal ini didukung oleh penelitian Puspita dkk. (2013) yang menyatakan bahwa peningkatan jumlah daun disebabkan oleh ketersediaan unsur hara, terutama unsur makro N.

Hasil infeksi CMA pada akar tanaman jagung (Gambar 2) menunjukkan pengaruh yang berbeda, kontrol dengan perlakuan. Perlakuan $100 \mathrm{~g}$ inokulum CMA memiliki derajat infeksi tanaman sebesar $58,66 \%$ tergolong kriteria kolonisasi tinggi. Tingginya infeksi pada perlakuan $100 \mathrm{~g}$ diduga tanaman banyak menghasilkan karbon hasil metabolisme. Fotosintat yang dihasilkan akan disalurkan ke akar tanaman sebagai sumber karbon bagi CMA untuk perkembangan dalam peningkatan pembentukan spora. Menurut Puspita dkk.
(2013) peningkatan derajat infeksi CMA pada tanaman dikarenakan meningkatnya metabolisme seperti fotosintesis berupa karbohidrat dan karbon yang dimanfaatkan CMA untuk tumbuh. Hasil ini didukung dengan berat basah akar dan berat kering akar menunjukkan rerata yang lebih tinggi dibandingkan dengan perlakuan lain (Tabel 3). Selain itu faktor yang dapat mempengaruhi pembentukan mikoriza dan derajat infeksi dari sel korteks inang berupa faktor lingkungan dan biotik, selain itu unsur hara, ketinggian, curah hujan, intensitas cahaya juga dapat mempengaruhi kepadatan spora (Pangaribuan, 2014).

Berdasarkan analisis statistik ke-9 parameter menunjukkan hasil tidak berbeda nyata dibandingkan dengan kontrol. Bobot basah akar dan bobot kering akar tanaman jagung yang terinfeksi CMA memiliki rerata bobot yang lebih tinggi dibandingkan dengan kontrol. Peningkatan bobot basah akar dan bobot kering akar mencapai 2627\% dibandingkan dengan kontrol (Tabel 3). CMA memiliki salah satu peran dalam penyerapan unsur hara. Penyerapan unsur $\mathrm{P}$ oleh mikoriza lebih cepat dibandingkan dengan pergerakan fosfat ke permukaan akar (Sagala dkk., 2013).

Peningkatan rerata tinggi tanaman jagung dengan pemberian CMA cenderung meningkat mencapai $3 \%$ pada perlakuan $100 \mathrm{~g}$ inokulum. Salah satu manfaat CMA dapat membantu penyerapan $\mathrm{P}$ organik di dalam tanah dan merubahnya menjadi $\mathrm{P}$ anorganik yang dapat diserap oleh tanaman serta membantu meningkatkan enzim fosfatase yang dihasilkan oleh CMA untuk 
pemanjangan sel-sel tanaman (Muis dkk., 2016).

Hasil penelitian laju pertumbuhan tanaman 10 HST tergolong fese logaritmik yaitu pertumbuhan lambat. Tetapi pada 2040 HST pertumbuhan semakin meningkat, tertinggi pada perlakuan $100 \mathrm{~g}$ sebesar 1,90 $\mathrm{cm} /$ hari dan terendah perlakuan $200 \mathrm{~g}$ sebesar 0,92 cm/hari. Umur tanaman 50-60 HST tinggi tanaman mencapai konstan sebesar 0,64 $\mathrm{cm} /$ hari. Pertumbuhan tanaman termasuk fase linier yaitu pertumbuhan tanaman ukuran berlangsung secara konstan. Selanjutnya akan dilanjutkan fase penuaan yang dicirikan dengan tumbuhan akan mencapai kematangan dan berakhir menua (Salisbury dan Ross, 1992).

Inokulasi CMA dapat menghasilkan beberapa hormon yang bisa digunakan pertumbuhan tanaman. Hormon auksin, giberelin, sitokinin yang dimanfaatkan tanaman untuk pertumbuhan dan perkembangannya. Hal ini didukung oleh penelitian terhadap CMA dapat menghasilkan hormon seperti sitokinin, auksin, dan giberelin (Hakiki, 2013). Perbedaan jenis tanaman akan memberikan pengaruh yang berbeda-beda terhadap pertumbuhan dan perkembangan tanaman. Kepekaan tanaman inang dengan keberadaan infeksi dan ketergantungan CMA akan berdampak menguntungkan Infeksi CMA diduga CMA dapat menghasilkan fenol yang dapat mencegah patogen menginfeksi tanaman. Ketahanan terhadap patogen dapat terjadi akibat infeksi mikoriza yang disebabkan adanya bahan yang dihasilkan oleh sel korteks yang berfungsi sebagai antibiotik berupa fenol, kuinon dan berbagai fitoaleksin yang dapat bagi tanaman yang kekurangan unsur $\mathrm{P}$ (Nurhayati, 2012).

Pengaruh Inokulasi Mikoriza terhadap Penyebab Penyakit Curvularia sp. pada Fase Pembibitan Tanaman Jagung.

Gejala penyakit Curvularia sp. pada tanaman jagung diawali dengan titik pada permukaan atas daun tua. Titik pada permukaan atas daun berwarna coklat kekuningan dengan selaput kuning kuning menyelubungi (Gambar 4.). Titik pada setiap daun memiliki infeksi yang berbeda. Menurut Susanto dan Prasetyo (2013), gejala penyakit Curvularia sp. pada tanaman kelapa sawit diawali dengan titik berwarna coklat dengan selaput kuning muda menyelubungi dan pusat bercak berwarna coklat.

Pengamatan pada 7-42 hari setelah infeksi (HSI) menunjukan perlakuan inokulum CMA mengakibatkan intensitas penyakit mengalami penurunan (Gambar 5). Semakin lama penginfeksian patogen, penurunan infeksi patogen lebih cepat perlakuan dibandingkan tanpa perlakuan. Pada perlakuan inokulasi $100 \mathrm{~g}$ mikoriza tidak ditemukan infeksi patogen setelah 28 HST.

Hal ini diduga CMA yang terinfeksi pada tanaman dapat mencegah patogen Curvularia sp. mengalami penetrasi yang berlanjutan pada tanaman.

menghambat patogen (Talanca dan Adnan, 2005). Simbiosis yang terjadi pada CMA dan tanaman akan membantu pembentukan fenol yang menyebabkan tanaman akan tahan terhadap patogen (Soenartiningsih, 2013). 


\section{SIMPULAN}

Cendawan Mikoriza Arbuskula (CMA) dapat digunakan sebagai biostimulator pertumbuhan tanaman jagung (Zea mays L.) CMA dapat meningkatkan berat basah akar sebesar 27,04\% dan berat kering akar sebesar $26,57 \%$ dibanding kontrol, persentase kolonisasi mencapai $58,66 \%$ pada pemberian inokulum 100g. Cendawan Mikoriza Arbuskula pada inokulum $100 \mathrm{~g}$ dapat menurunkan infeksi

\section{DAFTAR PUSTAKA}

Badan Penelitian Pengembangan Pertanian. 2016. Kerja sama Penelitian, Pengkajian, dan Pengembangan Pertanian Strategis KP4S-2017. Kementerian Pertanian.

Hakiki, T. N. 2013. Respon Pertumbuhan dan Produksi Kedelai (Glycine max L.) Merrill) yang Diberi Fungi Mikoriza Arbuskular pada Tanah Salin. Jurnal Online Agroekoteknologi 1(2):421-427.

Haris, A. T. dan A. Tenrirawe. 2014. Respon Beberapa Varietas terhadap Penyakit Utama Jagung di Kabupaten Kediri Jawa Timur. Jurnal Balai Penelitian Tanaman Serealia 67-78.

Masfufah, R. 2015. Pemanfaatan Cendawan Mikoriza Arbuskula (CMA) Indigenus Bali pada Tanaman Kedelai (Glycine max L.). Universitas Udayana, Bali. (Skripsi). Tidak dipublikasikan.

Muis, R, M. Ghulamahdi, M. Melati, Purwono, I. Mansur. 2016. Kompatibilitas Funfi Mikoriza Arbukular dengan Tanaman Kedelai pada Budi Daya Jenuh Air. patogen Curvularia sp. umur 28 HST pada tanaman jagung.

\section{UCAPAN TERIMAKASIH}

Kepada ibu Dr. Dra. Meitini W. Proborini. M.Sc (St) dan Dr. Ir. Made Ria Defiani selaku pembimbing I dan II yang telah memberikan bimbingan, masukan, saran, dan meluangkan waktunya dalam penyempurnaan jurnal ini.

Jurnal Penelitian Pertanian Tanaman Pangan 35(3):229-237.

Musfal, 2010. Potensi Cendawan Mikoriza Arbuskular untuk Meningkatkan Hasil Tanaman Jagung. Jurnal Litbang Pertanian 29(4):154-158.

Nurhayti, 2012. Pengaruh Berbagai Jenis Tanaman Inang dan Beberapa Jenis Sumber Inokulum terhadap Infektivitas dan Efektivitas Mikoriza. Jurnal Agrista 2(16).8086.

Pangaribuan, N. 2014. Penjaringan Cendawan Mikoriza Arbuskula Indigenous Dari Lahan Penanaman Jagung dan Kacang Kedelai pada Gambut Kalimantan Barat. Jurnal Agro 1(1):50-60.

Pechanova, O. dan T. Pechan. 2015. Interaksi Jagung-Patogen: Pertarungan yang Sedang Berjalan dari Perspektif Proteomika. Jurnal Internasional Molecular Sciences 16(12):28429-28448.

Puspita, D., A. Muhibuddin., T. Sumarni. 2013. Aplikasi CMA dan Bokashi dalam Meminimalisir Pemberian Pupuk Anorganik pada Produksi Benih Tanaman Jagung Ketan. 


\section{Jurnal Produksi Tanaman 5(1):398-407.}

Sagala, Y., A. S. Hanafiah, Razali. 2013. Peranan Mikoriza terhadap Pertumbuhan, Serapan $\mathrm{P}$ dan $\mathrm{Cd}$ Tanaman Sawi (Brassica juncea L.) Serta Kadar P dan Cd Andisol yang Diberi Pupuk Fosfat Alam 1(2):487-500.

Salisbury, F.B dan C.W. Ross.1992. Fisiologi Tumbuhan. Jidid Tiga Edisi Keempat. ITB. Bandung.

Soenartiningsih. 2013. Potensi Cendawan Mikoriza Arbuskular sebagai Media Pengendalian Penyakit Busuk Pelepah pada Jagung. Iptek Tanaman Pangan 1(8):48-53.

Suriani dan A. Muis, 2016. Fusarium pada Tanaman Jagung dan Pengendaliannya dengan Memanfaatkan Mikroba Endofit.
Balai Penelitian Tanaman Serealia 2(11):113-142.

Susanto, A. dan A. E. Prasetyo. 2013. Respons Curvularia lunata Penyebab Penyakit Bercak Daun Kelapa Sawit terhadap Berbagai Fungisida. Jurnal Fitopatologi Indonesia 6(9):165-172.

Susmawati dan W. Muda. 2014. Hama dan Penyakit Pada Tanaman Jagung dan Cara Pengendaliannya. Balai Besar Pelatihan Pertanian Binuang. Talanca dan Adnan, 2005. Mikoriza dan Manfaat pada Tanaman. Prosiding Seminar Ilmiah dan Pertemuan Tahunan PEI dan PFI XVI Komda Sul-Sel. Balai Penelitian Tanaman Serealia, Sulawesi Selatan. 